\title{
A new approach to analyze strategy map using an integrated BSC and FUZZY DEMATEL
}

\author{
Seyed Abdollah Heydariyeh ${ }^{\mathrm{a}}$, Mojtaba Javidnia ${ }^{\mathbf{b}^{*}}$, and Amir Mehdiabadi ${ }^{\mathbf{b}}$
}

${ }^{a}$ Department of Management, Islamic Azad University, Semnan Branch, Semnan, Iran

${ }^{b}$ Department of Management, Young Researchers Club, Islamic Azad University, Semnan Branch, Semnan, Iran

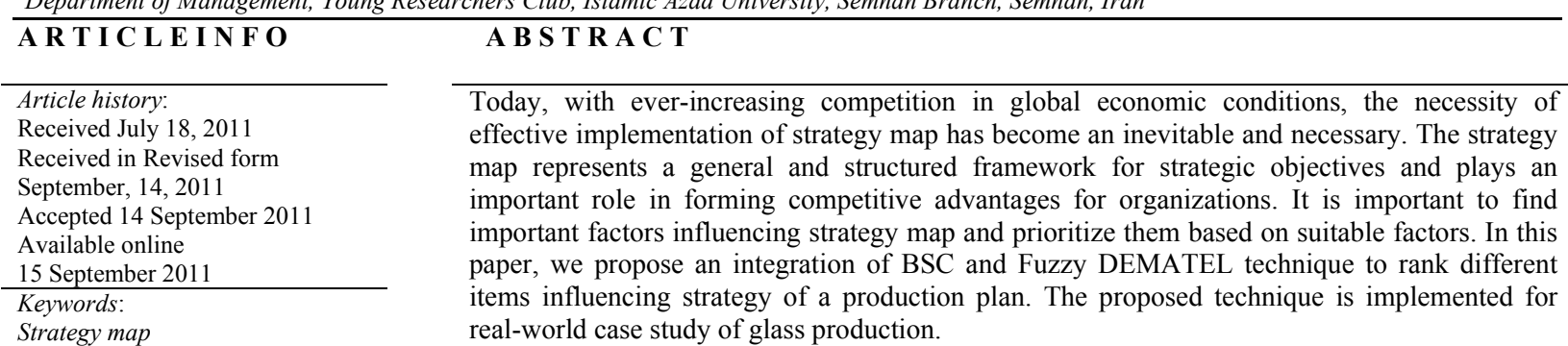

DEMATEL

Fuzzy DEMATEL

Balanced score card

\section{Introduction}

Globalization process has imposed the ever-increasing competitive pressure on organizations in all over the world since 1990. Some organizations have tried to promote simultaneously the efficiency and quality of their companies manufacturing unit in reaction to this process. The use of evaluation model proportionate to organizational objectives is an inevitable and necessary task along realization of this circumstance. It is always important to apply accurate evaluation models to organizations to design future strategies of organizations, effectively. It is also a vital task to adjust the functional objectives of staffs for achieving terminal objectives of the whole organization (Wu et al., 2011). Efficient and effective measuring systems are also considered as useful instruments enabling managers to supervise and control the organizational processes to achieve higher efficiency and higher performance (Wang et al., 2010).

There are many strategic control methods and techniques to evaluate organizational activities. One of the systematic and periodic methods to control and evaluate activities is balanced score card (BSC) method introduced by Kaplan and Norton (1992). BSC is an important technique to design organizational strategies and to form performance indexes. BSC is used to create a framework for perfect evaluation and to measure organizational performance for management system (Yuksel \&

* Corresponding author. Tel: +989122313702

E-mail addresses: mojtaba.javidnia@yahoo.com (M. Javadnia) 


\section{Table 1}

Previous studies in BSC

\begin{tabular}{|c|c|c|c|}
\hline Row & Title & Author/year & Content \\
\hline 1 & $\begin{array}{l}\text { Strategic performance measurement } \\
\text { in a healthcare organization: } \\
\text { A multiple criteria approach based on } \\
\text { balanced scorecard }\end{array}$ & $\begin{array}{l}\text { (Grigoroudis } \\
\text { et al., 2012). }\end{array}$ & $\begin{array}{l}\text { The main objective of this study is the representation of a performance } \\
\text { measurement system for healthcare organizations. Measurement indexes include } \\
\text { both financial and non financial indexes. Total findings indicated that growth and } \\
\text { learning aspect has more significance than other aspects in these organizations. }\end{array}$ \\
\hline 2 & $\begin{array}{l}\text { An integrated approach to evaluation } \\
\text { and planning of best practices }\end{array}$ & $\begin{array}{l}\text { (Xu \& Yeh, } \\
\text { 2012). }\end{array}$ & $\begin{array}{l}\text { A new evaluation model is presented by the use of multi criterion decision making } \\
\text { algorithm based on BSC framework in this paper to effectively measure the } \\
\text { relation between low level and high level objectives of the organization. }\end{array}$ \\
\hline 3 & $\begin{array}{l}\text { Extracting leanness criteria by } \\
\text { employing the concept of Balanced } \\
\text { Scorecard }\end{array}$ & $\begin{array}{l}\text { (Seyedhosseini } \\
\text { et al., 2011). }\end{array}$ & $\begin{array}{l}\text { The BSC concept is used for derivation of indexes with poor output in this paper. } \\
\text { For this aim, a set of organizational objectives are derived based on different BSC } \\
\text { aspects and by the use of organizational strategy map, and their performance was } \\
\text { then evaluated. }\end{array}$ \\
\hline 4 & $\begin{array}{l}\text { Performance evaluation of extension } \\
\text { education centers in universities } \\
\text { based on the balanced scorecard }\end{array}$ & $\begin{array}{l}\text { (Wu et al., } \\
\text { 2011). }\end{array}$ & $\begin{array}{l}36 \text { indexes were investigated by the use of DEMATEL, ANP and VICOR } \\
\text { methods in the form of } 4 \text { BSC aspects in Taiwan instruction center and were } \\
\text { finally introduced in sequence as the most important indexes in financial, } \\
\text { customer, internal business process, growth and learning: cost control, customer } \\
\text { continuity, service delivery and enhancing the quality of labor. }\end{array}$ \\
\hline 5 & $\begin{array}{l}\text { Developing strategic measurement } \\
\text { and improvement for the } \\
\text { biopharmaceutical firm: Using the } \\
\text { BSC hierarchy }\end{array}$ & $\begin{array}{l}\text { (Huang et al., } \\
\text { 2011). }\end{array}$ & $\begin{array}{l}\text { in this paper, Incorporation of } \mathrm{BSC} \text { and } \mathrm{AHP} \text { techniques was applied for } \\
\text { performance evaluation of biopharmaceutical firm from } 4 \mathrm{BSC} \text { aspects. }\end{array}$ \\
\hline 6 & $\begin{array}{l}\text { Implementation and performance } \\
\text { evaluation using the fuzzy network } \\
\text { balanced scorecard }\end{array}$ & 0). & $\begin{array}{l}\text { In this paper, BSC is applied for multi criterion evaluation in Taiwan universities. } \\
\text { Dematel technique was applied for investigation of mutual relations between } \\
\text { criterions. }\end{array}$ \\
\hline 7 & $\begin{array}{l}\text { Integrating hierarchical balanced } \\
\text { scorecard with non-additive fuzzy } \\
\text { integral for evaluating high } \\
\text { technology firm performance }\end{array}$ & $\begin{array}{l}\text { (Wang et al., } \\
\text { 2010). }\end{array}$ & $\begin{array}{l}\text { Results showed that the represented performance evaluation system can be } \\
\text { effective in removal of the gap between created objectives by top managers and } \\
\text { staffs. }\end{array}$ \\
\hline 8 & $\begin{array}{l}\text { A Fuzzy DEMATEL framework for } \\
\text { modeling cause and effect } \\
\text { relationships of strategy map }\end{array}$ & $\begin{array}{l}\text { (Jassbi et al., } \\
\text { 2011). }\end{array}$ & $\begin{array}{l}\text { In this paper, } 15 \text { available indexes in SAIPA strategy map were investigated from } \\
\text { BSC aspects and competitor examination, learning capacity, and rapid service } \\
\text { network based on new technologies updated service network for customer need } \\
\text { satisfaction and human capital learning and instructional policies and processes } \\
\text { factors were introduced as the effective factors. }\end{array}$ \\
\hline 9 & $\begin{array}{l}\text { Analyzing BSC and IC's usefulness } \\
\text { in nonprofit organizations }\end{array}$ & 010). & $\begin{array}{l}\text { in this research, The flow of knowledge transmission was investigated from } \\
\text { human capital, structural capital and relational capital aspects. }\end{array}$ \\
\hline 10 & $\begin{array}{l}\text { Using the fuzzy analytic network } \\
\text { process (ANP) for Balanced } \\
\text { Scorecard (BSC):A case study for a } \\
\text { manufacturing firm }\end{array}$ & $\begin{array}{l}\text { (Yuksel \& } \\
\text { Dag deviren, } \\
2010) .\end{array}$ & $\begin{array}{l}\text { BSC model and Fuzzy ANP are incorporated in this paper to determine business } \\
\text { performance level based on organizational strategies and objectives. Findings of } \\
\text { this incorporated model shows that more accurate and complete results are } \\
\text { achieved by incorporation of these two techniques. }\end{array}$ \\
\hline 11 & $\begin{array}{l}\text { Designing a knowledge-based system } \\
\text { for strategic planning: A balanced } \\
\text { scorecard perspective }\end{array}$ & (1, & $\begin{array}{l}\text { Ind AHP methods were applied for the } \\
\text { sed systems from financial, customer, } \\
\text { d growth aspects. }\end{array}$ \\
\hline 12 & $\begin{array}{l}\text { Evaluating petroleum supply chain } \\
\text { performance: Application of } \\
\text { analytical hierarchy process to } \\
\text { balanced scorecard }\end{array}$ & $\begin{array}{l}\text { (Varma et al., } \\
\text { 2008). }\end{array}$ & $\begin{array}{l}\text { In this paper, a combination of AHP and BSC is used for evaluating the } \\
\text { performance of petroleum supply chain. Selecting the determinant factors of } \\
\text { supply chain performance is credited by expert's opinions under four BSC } \\
\text { aspects. }\end{array}$ \\
\hline 13 & $\begin{array}{l}\text { evaluation of performance of society } \\
\text { assurance organization by used of } \\
\text { combination FDEA and BSC }\end{array}$ & $\begin{array}{l}\text { (Momeni et } \\
\text { al., 2010). }\end{array}$ & $\begin{array}{l}\text { In this paper, The extent of department's performance was first calculated by } \\
\text { balance scorecard and then, efficiency of this department was measured by the use } \\
\text { of FDEA with considering uncertain data in planned indexes by BSC model. }\end{array}$ \\
\hline 14 & 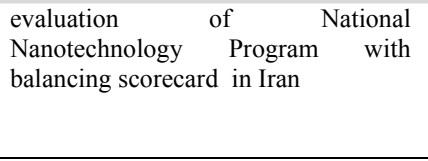 & $\begin{array}{l}\text { (Ghazi noori } \\
\& \\
\text { Tavasolizadeh, } \\
\text { 2009). }\end{array}$ & $\begin{array}{l}\text { This study was designed and implemented for application of the strategy map and } \\
\text { balance scorecard methods in technology strategy in national level which aim } \\
\text { were investigation of the efficiency and effectiveness of NANO technology } \\
\text { national plan of Iran to assure the accomplishment of NANO innovation chain in } \\
\text { national innovation framework. }\end{array}$ \\
\hline
\end{tabular}

Dag deviren, 2010). Among performed researches in BSC, we can point to mentioned researches in Table 1. BSC method concentrates important issues for business organizations, issues such as effective measuring of organizational performance and evaluating the organizational strategy (Grigoroudis et al., 2012). The most important capability of BSC is maintaining the balance among: (a) long-term strategies and short-term activities (b) long term and short term objectives (c) financial and non-financial indexes and (d) every four aspects of strategic. By possessing this superior characteristic, BSC is used as a framework for classifying the measuring indexes and criteria for evaluating a set of methods in different parts such as IT investments, research and development projects, ERP systems, banks and other industries (Xu \& Yeh, 2012). 
In this paper, we propose BSC for classifying strategic objectives of Parchsaz international company and related performance indexes. Although, there are many papers in BSC framework, but little attention has been paid to how this model is implemented in Fuzzy and ambiguous conditions (Tseng, 2010).

\section{Literature review}

\subsection{BSC concept}

BSC approach is a strategic planning system widely used in business and industry. BSC is actually a management system, which enables organizations to clearly define their objectives and strategies and then implement them (Olson \& Slater, 2002). Kaplan and Norton introduced BSC concept in 1992. This concept was first implemented as a performance evaluation system, especially for 12 companies in USA in 1992. The main objective of BSC was to replace and change the traditional performance evaluation model, which merely concentrated on financial indexes to obtain more complete and effective evaluation of organizational performance in this way by application of this model. Note that financial aspect is still considered as the most important aspect of organizational performance evaluation in BSC. However, other aspects of traditional model should also be considered, aspects such as customer, internal business processes and employee's growth and learning, so that performance evaluation model can achieve more balance and efficiency compared with past performance. These aspects are required for perception and implementation of a perfect performance evaluation system and formation of a general set of organization performance indexes for strategic investigation of all objectives and activities of an organization. The concept and meaning of the four aspects are as following:

1. Financial aspect: this aspect considers how organizations benefit from their strategic activities.

2. Customer aspect: this aspect pays attention to the issue that organizations should benefit of their inherent and available resources for the distinction among their competitors.

3. Internal business process aspect: all the strategic activities in an organization performed for satisfying stockholder and customer's expectations are investigated in this aspect. General process is started by perception of customer's needs and the operational and sale processes are performed after that.

4. Growth and learning aspect: if organizations want to maintain permanent activity and development, they should always rely on constant growth and innovation. Kaplan and Norton have expressed their opinions in this way: "organizations have to emphasize on some principals such as promotion of employee's capabilities and abilities, information system performance, persuasion and etc." This aspect includes three main criteria, which are employee satisfaction, employee continuity and efficiency. Companies and organizations should create performance evaluation indexes by these three criteria. Performance indexes must be unbiased and measurable based on organizational objectives. Index selection is so important for investigation of required industry performance, since we can enhance efficiency of manufacturing operations and create a lot of advantages for company by accurate investigation of these indexes. Performance key indexes should be investigated for achievement of strategic objectives in every four aspects of BSC (Wu et al., 2011). Kaplan and Norton believed that BSC includes affecting and influenced relationships among different indexes in selected aspects. Other different researchers similarly expressed experimental evidences in support of causal relations among different aspects of BSC (Schmidberger et al., 2009).These relationships point to the dependence among financial and non-financial indexes. A structured BSC method should include mutual relations among various aspects and measuring indexes of these aspects (Wang et al., 2010). Relationships among different aspects of BSC are indicated in Fig 1. 


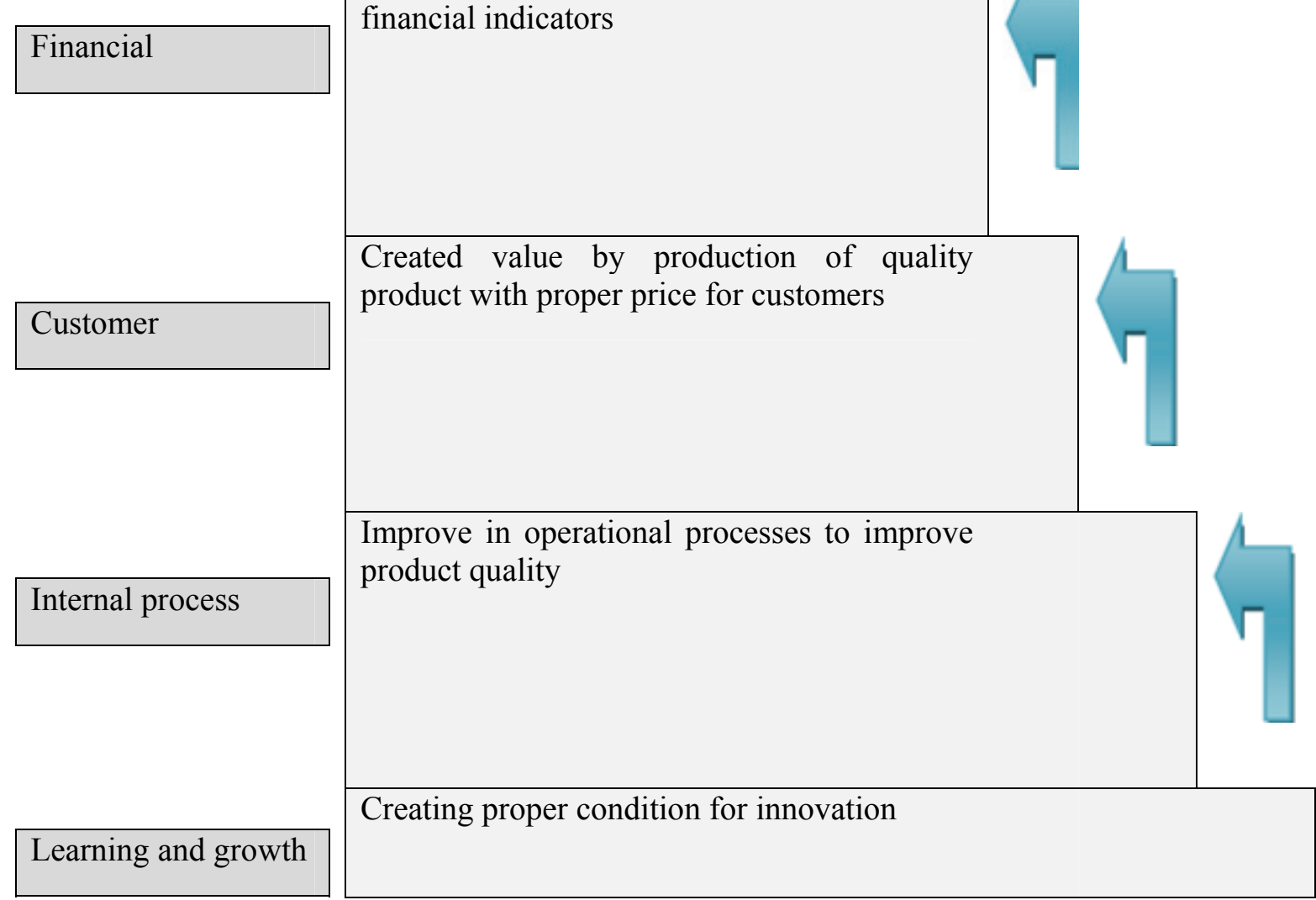

Fig. 1. The relationships between different components of BSC

In summary, we can say that BSC is a multi criteria investigation concept, which clearly shows the significance of organizational performance measurement (Tseng, 2010).

\subsection{Strategy map}

BSC innovators believe that successful implementation of organization strategy depends on the issue that organizational individuals conceive and understand the strategies. Note that, this issue requires creating complicated processes, which cause organizational illogical assets and investments change to tangible and logical outputs. BSC innovators have introduced instruments, which could indicate the link between structures of organization strategies by identifying key objectives of organization and conceptualization of causal relations among them called strategy map (Kaplan \& Norton, 2000).

In strategy map, the organization is segregated to four aspects, and key objectives of the organization interpolated in the strategic plan of the organization are classified in these four aspects. These aspects are practically indicator of all organizational parts and processes and include financial aspect, customer aspect, internal business process aspect, growth and learning aspect. Objectives such as developing profitable businesses, entrepreneurship, creating revenue, improving customer satisfaction, fostering talents and innovative creations in companies, enhancing employee and beneficiary's satisfaction are of organizational strategic objectives (Chytas, 2008). A basis is achieved by accurate drawing of causal relationships among organizational strategic objectives according to these four aspects, which can be used as a basis for balance scorecard.

\subsection{Parchsaz international company (www.parchsaz.com)}

Parchsaz international company as the manufacturer of all kinds of required rivet, pin, special part for automobile industries of country, started its operation in 1983 and its motto was "tenacious customers 
are our close friends". One of the main policies of this company is to attract the target market customer satisfaction by providing the needs and measuring customer satisfaction with respect to the purchase mass. The company tries to reduce the costs by the aim of reducing sale price to make competition based on business plan in global target market. We need to consider all instructions and permanent improvements, employee participation, developing culture of quality and moving towards zero deviation from desirable policy. This company is now considered as one of the greatest and most reliable companies of the zone by manufacturing more than 20 different kinds of products. The main customers and markets of this company's product are territorial and foreign automobile companies such as firms located in Azerbaijan, Emirate, Armenia and Iraq. Since automobile industry is one of the industries, which has strongly been considered and criticized by customers, we need to pay special attention to manufacturing products of this company to attract automobile companies.

\subsection{Fuzzy DEMATEL}

DEMATEL was first introduced at Battelle Memorial Institute of Geneva Research Center. This method was applied for complicated problems of the world such as famine, energy, environmental protection and etc in that time (Fontela \& Gabus, 1976). DEMATEL is one the multi criteria decision making instruments and has the ability to convert the qualitative designs to the quantitative analysis (Lee et al., 2011).The aim of DEMATEL is to convert the relationships among various criteria, causal dimensions from a complex system to an understandable structural model of that system (Dalalah et al., 2011). All criteria of a system, directly or indirectly, are mutually related to each other in a general reciprocal system. So any change in one of criteria will influence on other criterions (Tzeng et al., 2007). This technique is successfully applied in other circumstances such as development methods, management systems, electronic learning evaluation, knowledge management, etc. (Kuoa \& Liang, 2011). Many forms in various countries such as Japan, Korea and Taiwan have widely used DEMATEL technique for successful solving of different problems in different fields (Lin \& $\mathrm{Wu}$, 2008). The following summarizes the necessary steps of DEMATEL model we need to implement.

1. First, We need to specify evaluation factors according to expert committee's opinion and research background.

2. Next, We determine how each factor influences on the whole system, according to expert's opinion. To do so, we use discussed wordy expressions in Table2. Then, we use CFC method Eqs (19) to convert the fuzzy results into crisp value.

\section{Table 2}

The correspondence of linguistic terms and values

\begin{tabular}{ll}
\hline Linguistic values & Linguistic terms \\
\hline$[0.75,1,1]$ & Very high influence(VH) \\
{$[0.5,0.75,1]$} & High influence(H) \\
{$[0.25,0.5,0.75]$} & Low influence $(\mathrm{L})$ \\
{$[0,0.25,0.5]$} & Very low influence (VL) \\
{$[0,0,0.25]$} & No influence (NO) \\
\hline
\end{tabular}

$$
\begin{aligned}
& X L_{i j}^{k}=\left(L_{i j}^{k}-\min _{1 \leq k \leq k} L_{i j}^{k}\right) / \Delta_{\min }^{\max } \\
& X M_{i j}^{k}=\left(M_{i j}^{k}-\min _{1 \leq k \leq k} L_{i j}^{k}\right) / \Delta_{\min }^{\max } \\
& X r_{i j}^{k}=\left(r_{i j}^{k}-\min _{1 \leq k \leq k} L_{i j}^{k}\right) / \Delta_{\min }^{\max } \\
& \Delta_{\min }^{\max }=\max r_{i j}^{k}-\min L_{i j}^{k}
\end{aligned}
$$


$X l s_{i j}^{k}=\frac{X m_{i j}^{k}}{\left(1+X m_{i j}^{k}-X l_{i j}^{k}\right)}$

$X r S \underset{i j}{k}=\frac{X r_{i j}{ }^{k}}{\left(1+X r_{i j}^{k}-X m_{i j}^{k}\right)}$

$X_{i j}^{k}=\left\lfloor X l s_{i j}^{k}\left(1-X l s_{i j}^{k}\right)+X r s_{i j}^{k} \cdot X r s_{i j}^{k}\right\rfloor /\left(1+X r s_{i j}^{k}-X l s_{i j}^{k}\right)$

$B N P_{i j}^{k}=\min L_{i j}^{k}+X_{i j}^{k} \Delta_{\min }^{\max }$

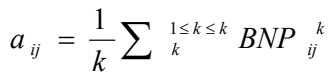

$\mathrm{A}=\left[\mathrm{a}_{\mathrm{ij}}\right]$ is direct relations matrix of experts opinions.

3. Now we can determine total relationship matrix T-I, which is an identity matrix $\mathbf{n} \times \mathbf{n}$ and $\mathrm{T}=\left[\mathrm{t}_{\mathrm{ij}}\right]$ elements indicate the direct and indirect influences of factor $i$ on factor $j$. Therefore, matrix $T$ represents the indicator of general relations between each pair factor in the system. Matrix D is the normalized matrix. $D=\left[d_{i j}\right], 0 \leq d_{\mathrm{jj}} \leq 1$.

$D=\frac{1}{\max _{\sin } \Sigma_{j=1}^{n} a_{i j}} A$

$T=D(I-D)^{-1}$

4. In this step we calculate the summation of each row and column of $T$ matrix, where the sum of row $i$ is an indicator for all direct and indirect influences of $i$ factor on all other factors and so can call $r_{i}$ as the influencing degree. $C_{j}$ is similarly, the column summation and we can call it as influenced degree of $j$ factor.

$r_{i}=\Sigma_{1 \unlhd i \Xi m} t_{i j}$

$C_{j}=\Sigma_{1 \Xi i \leq n} t_{i j}$

Therefore, when $i=j, r_{i}+C_{i}$ shows both the influence which $i$ factor on other factors of system and also the influences of other factors of system on $i$ factor. Therefore, $r_{i}+C_{i}$ shows the significant degree of $i$ factor in whole system, and $n_{i}-C_{i}$ indeed shows the influence of $i$ on system. If $r_{i}-C_{i}$ is positive, $i$ factor belongs to the cause group and if $r_{i}-C_{i}$ is negative, $i$ factor belongs to the effect group.

5. Finally, We show the diagram of factors influencing on $r_{i}-C_{i}$ and $r_{i}+C_{i}$ bases. This diagram is drawn by $\left(r_{i}+C_{i}, n_{i}-C_{i}\right)$ coordinate (Huang, 2009).

\section{Research methodology}

With respect to the significance of investigating the total processes of regarding company, we consider the strategy map of this company for BSC implementation. Then, we have identified 15 strategic objectives of this company by distributing questionnaires among 5 top managers of different parts of company and then analyze the influences of those objectives on each other by Fuzzy Logic and DEMATEL technique. The strategy map plan of Parchsaz international company is indicated in Fig. 2. 


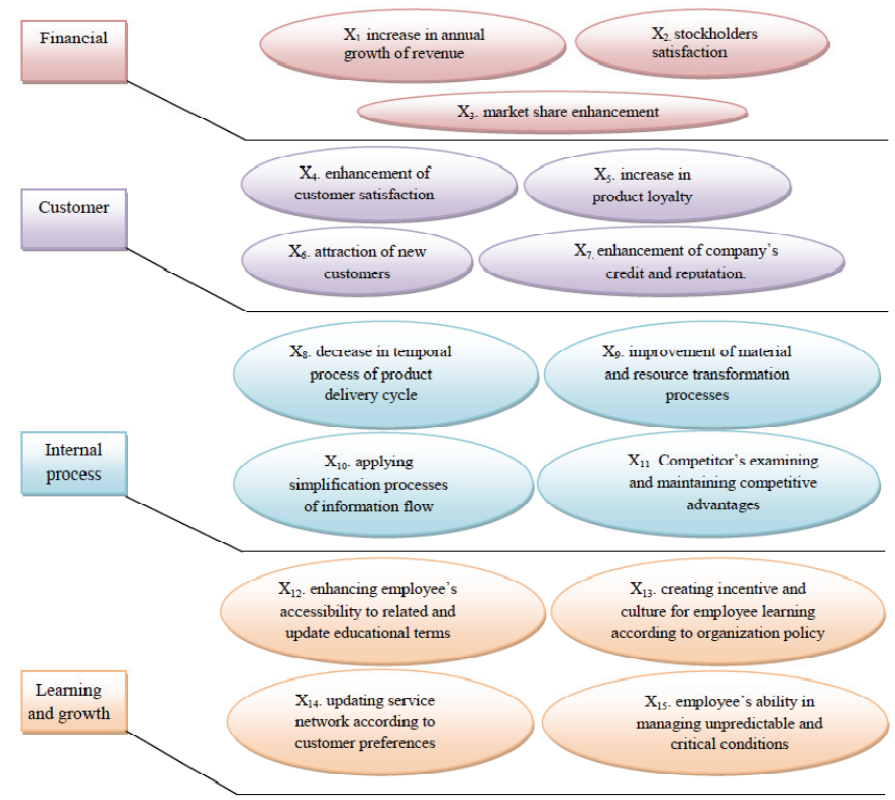

Fig.2. The strategy map plan of Parchsaz international company

Then, direct relations matrix of experts' opinions have been obtained after Defuzzification stages shown in Table 3.

Table 3

Direct relations matrix

\begin{tabular}{|c|c|c|c|c|c|c|c|c|c|c|c|c|c|c|c|}
\hline & X1 & X2 & X3 & X4 & X5 & X6 & X7 & X8 & X9 & $\mathbf{X 1 0}$ & X11 & X12 & X13 & X14 & X15 \\
\hline $\mathrm{X} 1$ & 0 & 0.957 & 0.833 & 0.791 & 0.309 & 0.359 & 0.833 & 0.309 & 0.499 & 0.254 & 0.041 & 0.602 & 0.499 & 0.791 & 0.699 \\
\hline $\mathrm{X} 2$ & 0.359 & 0 & 0.499 & 0.25 & 0.25 & 0.309 & 0.25 & 0.309 & 0.254 & 0.499 & 0.309 & 0.309 & 0.25 & 0.499 & 0.254 \\
\hline $\mathrm{X} 3$ & 0.957 & 0.828 & 0 & 0.25 & 0.25 & 0.25 & 0.202 & 0.499 & 0.309 & 0.309 & 0.25 & 0.041 & 0.041 & 0.25 & 0.041 \\
\hline $\mathrm{X} 4$ & 0.359 & 0.359 & 0.957 & 0 & 0.957 & 0.957 & 0.957 & 0.041 & 0.041 & 0.041 & 0.041 & 0.25 & 0.309 & 0.833 & 0.124 \\
\hline X5 & 0.833 & 0.359 & 0.833 & 0.828 & 0 & 0.602 & 0.957 & 0.041 & 0.041 & 0.041 & 0.041 & 0.25 & 0.25 & 0.499 & 0.041 \\
\hline X6 & 0.833 & 0.669 & 0.957 & 0.041 & 0.041 & 0 & 0.874 & 0.041 & 0.041 & 0.041 & 0.041 & 0.25 & 0.041 & 0.309 & 0.041 \\
\hline X7 & 0.957 & 0.669 & 0.957 & 0.957 & 0.957 & 0.957 & 0 & 0.254 & 0.499 & 0.254 & 0.499 & 0.25 & 0.25 & 0.828 & 0.499 \\
\hline X8 & 0.833 & 0.202 & 0.874 & 0.25 & 0.25 & 0.25 & 0.874 & 0 & 0.359 & 0.254 & 0.828 & 0.041 & 0.041 & 0.833 & 0.499 \\
\hline X9 & 0.957 & 0.828 & 0.833 & 0.957 & 0.957 & 0.957 & 0.957 & 0.957 & 0 & 0.309 & 0.791 & 0.041 & 0.041 & 0.833 & 0.828 \\
\hline X10 & 0.833 & 0.791 & 0.828 & 0.833 & 0.874 & 0.828 & 0.828 & 0.874 & 0.874 & 0 & 0.833 & 0.309 & 0.309 & 0.833 & 0.833 \\
\hline $\mathrm{X} 11$ & 0.791 & 0.669 & 0.874 & 0.467 & 0.467 & 0.669 & 0.791 & 0.12 & 0.2 & 0.2 & 0 & 0.499 & 0.467 & 0.669 & 0.041 \\
\hline $\mathrm{X} 12$ & 0.833 & 0.669 & 0.791 & 0.91 & 0.91 & 0.833 & 0.791 & 0.602 & 0.669 & 0.91 & 0.602 & 0 & 0.2 & 0.791 & 0.833 \\
\hline X13 & 0.25 & 0.602 & 0.828 & 0.2 & 0.124 & 0.082 & 0.082 & 0.25 & 0.25 & 0.25 & 0.25 & 0.041 & 0 & 0.041 & 0.041 \\
\hline X14 & 0.791 & 0.669 & 0.791 & 0.957 & 0.91 & 0.791 & 0.669 & 0.602 & 0.2 & 0.2 & 0.25 & 0.041 & 0.041 & 0 & 0.041 \\
\hline X15 & 0.2 & 0.254 & 0.25 & 0.25 & 0.25 & 0.041 & 0.254 & 0.041 & 0.041 & 0.041 & 0.499 & 0.041 & 0.041 & 0.041 & 0 \\
\hline
\end{tabular}

\section{According to steps that mentioned above:}

\section{Table 4}

General relations matrix - $\mathrm{T}$ Matrix

\begin{tabular}{lllllllllllllllll}
\hline & $\mathrm{X} 1$ & $\mathrm{X} 2$ & $\mathrm{X} 3$ & $\mathrm{X} 4$ & $\mathrm{X} 5$ & $\mathrm{X} 6$ & $\mathrm{X} 7$ & $\mathrm{X} 8$ & $\mathrm{X} 9$ & $\mathrm{X} 10$ & $\mathrm{X} 11$ & $\mathrm{X} 12$ & $\mathrm{X} 13$ & $\mathrm{X} 14$ & $\mathrm{X} 15$ \\
\hline $\mathrm{X} 1$ & 0.109 & 0.181 & 0.195 & 0.159 & 0.114 & 0.122 & 0.173 & 0.082 & 0.091 & 0.065 & 0.057 & 0.088 & 0.076 & 0.159 & 0.109 \\
$\mathrm{X} 2$ & 0.103 & 0.063 & 0.122 & 0.080 & 0.076 & 0.084 & 0.088 & 0.064 & 0.054 & 0.070 & 0.062 & 0.051 & 0.043 & 0.102 & 0.055 \\
$\mathrm{X} 3$ & 0.152 & 0.135 & 0.076 & 0.078 & 0.072 & 0.076 & 0.083 & 0.079 & 0.058 & 0.053 & 0.055 & 0.029 & 0.026 & 0.081 & 0.037 \\
$\mathrm{X} 4$ & 0.124 & 0.111 & 0.183 & 0.071 & 0.149 & 0.155 & 0.164 & 0.044 & 0.039 & 0.034 & 0.039 & 0.051 & 0.053 & 0.142 & 0.045 \\
$\mathrm{X} 5$ & 0.156 & 0.107 & 0.166 & 0.140 & 0.062 & 0.121 & 0.160 & 0.041 & 0.039 & 0.033 & 0.037 & 0.051 & 0.048 & 0.112 & 0.039 \\
$\mathrm{X} 6$ & 0.138 & 0.119 & 0.154 & 0.056 & 0.051 & 0.049 & 0.132 & 0.036 & 0.034 & 0.029 & 0.032 & 0.045 & 0.024 & 0.080 & 0.034 \\
$\mathrm{X} 7$ & 0.208 & 0.169 & 0.222 & 0.183 & 0.175 & 0.183 & 0.117 & 0.080 & 0.093 & 0.065 & 0.097 & 0.065 & 0.060 & 0.173 & 0.096 \\
$\mathrm{X} 8$ & 0.171 & 0.105 & 0.182 & 0.102 & 0.095 & 0.100 & 0.165 & 0.046 & 0.073 & 0.056 & 0.118 & 0.037 & 0.033 & 0.152 & 0.086 \\
$\mathrm{X} 9$ & 0.228 & 0.198 & 0.233 & 0.198 & 0.190 & 0.199 & 0.220 & 0.149 & 0.057 & 0.075 & 0.135 & 0.053 & 0.047 & 0.192 & 0.134 \\
$\mathrm{X} 10$ & 0.227 & 0.204 & 0.243 & 0.196 & 0.191 & 0.196 & 0.217 & 0.149 & 0.140 & 1.052 & 0.146 & 0.078 & 0.073 & 0.199 & 0.142 \\
$\mathrm{X} 11$ & 0.172 & 0.152 & 0.191 & 0.124 & 0.117 & 0.141 & 0.162 & 0.060 & 0.062 & 0.056 & 1.044 & 0.079 & 0.073 & 0.142 & 0.048 \\
X12 & 0.225 & 0.192 & 0.238 & 0.203 & 0.195 & 0.196 & 0.213 & 0.126 & 0.123 & 0.133 & 0.125 & 1.050 & 0.063 & 0.195 & 0.143 \\
X13 & 0.071 & 0.097 & 0.125 & 0.054 & 0.045 & 0.044 & 0.049 & 0.048 & 0.044 & 0.041 & 0.046 & 0.020 & 1.014 & 0.043 & 0.025 \\
X14 & 0.171 & 0.147 & 0.183 & 0.163 & 0.153 & 0.151 & 0.155 & 0.098 & 0.058 & 0.051 & 0.065 & 0.039 & 0.035 & 1.083 & 0.046 \\
X15 & 0.051 & 0.052 & 0.059 & 0.049 & 0.047 & 0.031 & 0.053 & 0.018 & 0.017 & 0.015 & 0.059 & 0.016 & 0.015 & 0.031 & 1.013 \\
\hline
\end{tabular}


Table 5

Calculating the influences of each factor

\begin{tabular}{lcccc}
\hline & $\boldsymbol{r}_{\boldsymbol{i}}$ & $\boldsymbol{C}_{\boldsymbol{i}}$ & $\boldsymbol{r}_{\boldsymbol{i}}+\boldsymbol{C}_{\boldsymbol{i}}$ & $\boldsymbol{r}_{\boldsymbol{i}}-\boldsymbol{C}_{\boldsymbol{i}}$ \\
\hline $\mathrm{X}_{1}$ & 1.781 & 2.306 & 4.087 & -0.525 \\
$\mathrm{X}_{2}$ & 1.116 & 2.033 & 3.149 & -0.917 \\
$\mathrm{X}_{3}$ & 1.089 & 2.571 & 3.660 & -1.482 \\
$\mathrm{X}_{4}$ & 1.404 & 1.854 & 3.258 & -0.450 \\
$\mathrm{X}_{5}$ & 1.313 & 1.732 & 3.045 & -0.419 \\
$\mathrm{X}_{6}$ & 1.013 & 1.847 & 2.860 & -0.834 \\
$\mathrm{X}_{7}$ & 1.985 & 2.152 & 4.137 & -0.167 \\
$\mathrm{X}_{8}$ & 1.520 & 1.117 & 2.637 & 0.403 \\
$\mathrm{X}_{9}$ & 2.308 & 0.981 & 3.289 & 1.327 \\
$\mathrm{X}_{10}$ & 2.453 & 0.829 & 3.282 & 1.624 \\
$\mathrm{X}_{11}$ & 1.623 & 1.119 & 2.742 & 0.504 \\
$\mathrm{X}_{12}$ & 2.420 & 0.752 & 3.172 & 1.668 \\
$\mathrm{X}_{13}$ & 0.764 & 0.683 & 0.081 \\
$\mathrm{X}_{14}$ & 1.598 & 1.886 & 3.447 & -0.288 \\
$\mathrm{X}_{15}$ & 0.529 & 1.052 & 1.581 & -0.523 \\
\hline
\end{tabular}

Finally, Fig. 3 shows the results of casual diagram of Fuzzy DEMATEL technique.

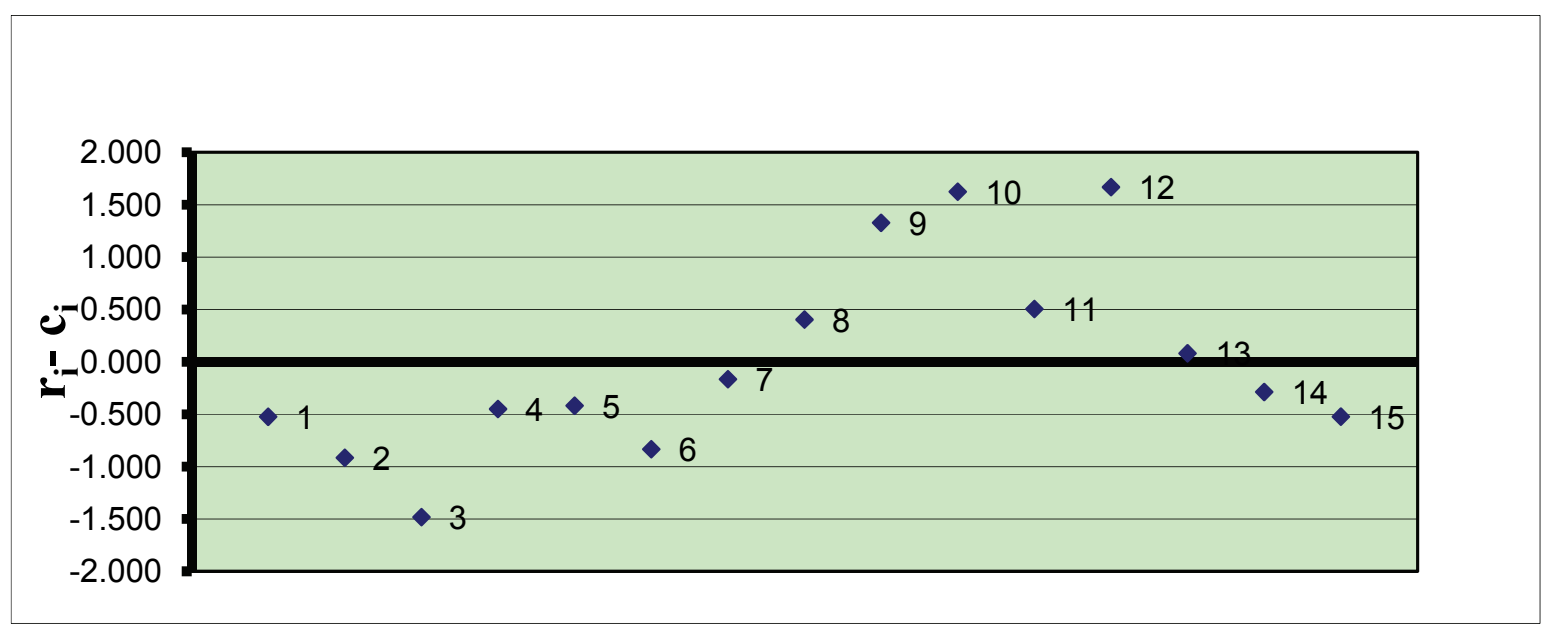

Fig.3. The casual diagram

\section{Conclusion}

In modern competitive industrial world, traits such as process integration, necessity of cooperation among them, effective relationship with customers and sellers, variety of customer demands, global scale and wise employees are constantly emphasized by organizations to maintain their competitive advantages in this way and to promote it if possible.

By considering the strategy map as a basis for balance scorecard, a pattern is produced, which leads to accelerating successful implementation of balance scorecard. The strategy map enables managers to identify and extract key objectives (strategic) for modeling causal relations between organizational strategic objectives. In this paper, strategic objectives available in strategy map of Parchsaz international company have been investigated from four aspects of financial, customer, internal business process and learning and growth. For achieve this purpose, we have used a fuzzy DEMATEL method, as a powerful structural decision making system, for investigation cause and effect relationships of the strategy map. As the shown in Fig. 3, the strategic objectives are divided into two groups:

1. Cause group which includes $X_{12}, X_{10}, X_{9}, X_{11}, X_{8}$ and $X_{13}$.

2. Effect group which includes $X_{3}, X_{2}, X_{6}, X_{1}, X_{15}, X_{4}, X_{5}, X_{14}$ and $X_{7}$. 
By analyzing obtained results, the importance of growth, learning and internal business are clearly prominent in the strategy map of this company and top manager of this company are required to investment on this objectives for achievement of higher competitive advantage. The results also point to the dependence among financial and non financial indexes. Companies consider the growth and learning aspect for developing new processes and technologies for decreasing the costs and enhancing the efficiency in internal business processes of company. Finally, considering the growth and learning aspect leads to customer satisfaction and customer attraction, this ultimately leads to higher financial results. Therefore, a structured BSC method should include mutual relations among different aspects and measuring indexes of these aspects.

\section{Acknowledgement}

The authors would like to thank Islamic Azad University Young Researchers Club for financially supporting this research.

\section{References}

Chytas, P. (2008). A proactive fuzzy cognitive balanced scorecard. IEEE World Congress on Computational Intelligence Systems, 1331- 1338.

Dalalah, D., Hayajneh, M., \& Batieha, F. (2011). A fuzzy multi-criteria decision making model for supplier selection. Expert Systems with Applications, 38, 8384-8391.

Fontela, E., \& Gabus, A. (1976). The DEMATEL observer. DEMATEL 1976 Report. Switzerland, Geneva: Battelle Geneva Research Center.

Ghazi Noori, S., \& Tavasolizadeh, S. (2009). Assessing national Iranian nanotechnology initiative by BSC; explaining the role of social capital as a miss. Journal of Science \& Technology, 4 , 49- 58.

Grigoroudis, E., Orfanoudaki, E., \& Zopounidis, C. (2012). Strategic performance measurement in a healthcare organization: Amultiple criteria approach based on balanced score. Journal of Omega, 40, 104-119.

Huang, H. C. (2009). Designing a knowledge-based system for strategic planning: A balanced scorecard perspective. The journal Of Expert Systems with Applications, 36(1), 209-218.

Huang.H.C., Lai.M.C., \& Lin.L.H.(2011). Developing strategic measurement and improvement for the biopharmaceutical firm: Using the BSC hierarchy. Expert Systems with Applications, 38, $4875-4881$.

Jassbi, J., Mohamadnejad, F., \& Nasrollahzadeh, H. (2011). A Fuzzy DEMATEL framework for modeling cause and effect relationships of strategy map. Expert Systems with Applications, 38, 5967-5973.

Kaplan, R., \& Norton, D. (2000). The strategy-focused organization: How balanced scorecard companies thrive in the new business environment, Harvard Business School Press.

Kong, E. (2010). Analyzing BSC and IC's usefulness in nonprofit organizations. Journal of Intellectual Capital, 11(3), 284-304.

Kuoa, M.S., \& Liang, G.S. (2011). A novel hybrid decision-making model for selecting locations in a fuzzy environment. Mathematical and Computer Modelling, 54, 88-104.

Lee, Y. C., Lee, M. L., Yen, T. M., \& Huang, T. H. (2011). Analysis of fuzzy Decision Making Trial and Evaluation Laboratory on technology acceptance model. Expert Systems with Applications, 110.

Lin, C. J., \& Wu, W. W. (2008). A causal analytical method for group decision-making under fuzzy environment. Expert Systems with Applications, 34(1), 205-213.

Momeni, M., Khodaei, S., \& Bashiri, M. (2010). Evaluation of performance of society assurance organization by used of combination FDEA and BSC. Journal of Industrial Management, 3, 137152. 
Olson, E.M., \& Slater, S.F. (2002). The balanced scorecard, competitive strategy, and performance. Business Horizons ,45, 11-16.

Schmidberger, S., Bals, L., Hartmann, E., \& Jahns, C. (2009). Ground handling services at European hub airports: development of a performance measurement system for benchmarking. International Journal of Production Economics, 117, 104-111.

Seyedhosseini, S.M., Taleghani, A.E., Bakhsha, A., \& Partovi, S. (2011). Extracting leanness criteria by employing the concept of Balanced Scorecard. Expert Systems with Applications, 38, 1045410461.

Tseng, M. L. (2010). Implementation and performance evaluation using the fuzzy network balanced scorecard, Journal of Computers \& Education, 55, 188-201.

Tzeng, G. H., Chiang, C. H., \& Li, C. W. (2007). Evaluating intertwined effects in elearning programs: A novel hybrid MCDM model based on factor analysis and DEMATEL. Expert Systems with Applications, 32, 1028-1044.

Varma, S., Wadhwa, S., \& Deshmukh, S. G. (2008). Evaluating petroleum supply chain performance: Application of analytical hierarchy process to balanced scorecard. Asia Pacific Journal of Marketing and Logistics, 20(3), 343-356.

Wang, C.H., Lu, I.Y., \& Chen, C.B. (2010). Integrating hierarchical balanced scorecard with nonadditive fuzzy integral for evaluating high technology firm performance. International Journal of Production Economics, 128, 413-426.

Wu, H.Y., Lin, Y.K., \& Chang, C.H. (2011). Performance evaluation of extension education centers in universities based on the balanced scorecard, Journal of Evaluation and Program Planning 34, $37-50$.

$\mathrm{Xu}, \mathrm{Y} .$, \& Yeh, C.H. (2012). An integrated approach to evaluation and planning of best practices, Omega, 40, 65-78.

Yuksel, I., \& Dag deviren, M. (2010).Using the fuzzy analytic network process (ANP) for Balanced Scorecard (BSC): A case study for a manufacturing firm. Expert Systems with Applications, 37 , $1270-1278$.

Zhou, Q., Huang, W., \& Zhang, Y. (2010). Identifying success factors in emergency management using a fuzzy DEMATEL method. Safety Science, 49(2), 243- 252. 